\title{
Broad-Spectrum Coronavirus Fusion Inhibitors to Combat COVID-19 and Other Emerging Coronavirus Diseases
}

\author{
Xinling Wang ${ }^{1}{ }^{\oplus}$, Shuai Xia ${ }^{1}{ }^{1}$, Qian Wang ${ }^{1}$, Wei Xu ${ }^{1}$, Weihua $\mathrm{Li}^{2}, \mathrm{Lu} \mathrm{Lu}^{1, *}$ and \\ Shibo Jiang $1,2, *$ (i) \\ 1 Key Laboratory of Medical Molecular Virology (MOE/NHC/CAMS), School of Basic Medical Sciences, \\ Fudan University, Shanghai 200032, China; 18111010064@fudan.edu.cn (X.W.); \\ 15111010053@fudan.edu.cn (S.X.); Wang_qian@fudan.edu.cn (Q.W.); Xuwei0576@126.com (W.X.) \\ 2 Key Laboratory of Reproduction Regulation of National Health Commission, (Shanghai Institute of Planned \\ Parenthood Research), Fudan University, Shanghai 200032, China; weihua.li@sippr.org.cn \\ * Correspondence: lul@fudan.edu.cn (L.L.); shibojiang@fudan.edu.cn (S.J.); \\ Tel.: +86-21-54237671 (L.L.); +86-21-54237673 (S.J.)
}

Received: 9 May 2020; Accepted: 26 May 2020; Published: 28 May 2020

\begin{abstract}
In the past 17 years, three novel coronaviruses have caused severe acute respiratory syndrome (SARS), Middle East respiratory syndrome (MERS), and the coronavirus disease 2019 (COVID-19). As emerging infectious diseases, they were characterized by their novel pathogens and transmissibility without available clinical drugs or vaccines. This is especially true for the newly identified COVID-19 caused by SARS coronavirus 2 (SARS-CoV-2) for which, to date, no specific antiviral drugs or vaccines have been approved. Similar to SARS and MERS, the lag time in the development of therapeutics is likely to take months to years. These facts call for the development of broad-spectrum anti-coronavirus drugs targeting a conserved target site. This review will systematically describe potential broad-spectrum coronavirus fusion inhibitors, including antibodies, protease inhibitors, and peptide fusion inhibitors, along with a discussion of their advantages and disadvantages.
\end{abstract}

Keywords: COVID-19; peptide; antibody; fusion inhibitor; entry inhibitor; protease inhibitor

\section{Introduction}

The pandemic of coronavirus disease (COVID-19) was caused by the novel coronavirus 2019 (2019-nCoV) [1], also known as human coronavirus 2019 (HCoV-19) [2] or severe acute respiratory syndrome coronavirus 2 (SARS-CoV-2) [3]. It has posed a serious threat to global public health, as well as social and economic stability, thus calling for the development of highly effective therapeutics and prophylactics [4].

In its research and development blueprint, the World Health Organization (WHO) announced the first list of prioritized diseases in 2015 and formally announced it on 9 February 2018 [5]. Apart from SARS and MERS, Disease $X$ has sparked an international epidemic caused by an unknown pathogen that would be highly transmissible among humans. Jiang et al. suggested that the first reported pneumonia cluster in Wuhan in December of 2019, with its etiology unknown (later known as 2019-nCoV), should be recognized as the first Disease X [6]. However, this was the third coronavirus that has caused severe pneumonia in humans over the past twenty years. SARS-CoV infection resulted in 8096 cases and 774 deaths [7], whereas confirmed MERS cases numbered about 2494, including 858 deaths [8]. As of 25 April 2020, 2,724,809 COVID-19 cases and 187,847 deaths were confirmed [9], with no signs of abatement. As noted previously, vaccines and FDA-approved drugs still remain out of 
clinical reach. These facts call for the development of broad-spectrum anti-coronavirus drugs targeting a conserved target site that would address the current urgency and those coronavirus outbreaks that are likely to emerge in the future.

Coronaviruses (CoVs) comprise four genera-alphacoronavirus, betacoronavirus, gammacoronavirus, and deltacoronavirus. SARS-CoV-2 belongs to $\beta$-coronavirus. In this group, highly pathogenic SARS-CoV and MERS-CoV caused severe human diseases in 2002 and 2012, respectively [10,11]. The genome sequence of SARS-CoV-2 is $79.5 \%$ homologous to SARS-CoV and $96 \%$ identical to bat SARS-related coronavirus (SARSr-CoV) [12,13]. Four low-pathogenicity coronaviruses are also epidemic in humans-HCoV-NL63, HCoV-229E, HCoV-OC43, and HCoV-HKU1. The viral genome encodes four structural proteins, spike protein $(\mathrm{S})$, membrane protein $(\mathrm{M})$, envelope protein $(\mathrm{E})$, and nucleocapsid protein $(\mathrm{N})$ (Figure 1a). The S protein is a type I transmembrane glycoprotein, and it includes an extracellular domain, transmembrane domain, and intracellular domain. The extracellular domain of the $S$ protein contains two subunits, $\mathrm{S} 1$ and $\mathrm{S} 2$, each playing a different role in receptor recognition, binding, and membrane fusion (Figure 1b). The S1 subunit includes the N-terminal domain (NTD) and C-terminal domain (CTD). Generally, the receptor-binding domain (RBD) is located in the CTD (Figure 1c). NTD mediates the binding between the virus and sugar-based receptors, and the CTD mediates viral binding to the protein-based receptor [14]. SARS-CoV, SARS-CoV-2, and MERS-CoV utilize the CTD to bind their respective receptors. Receptor recognition and binding trigger membrane fusion between the virus and the target cell. We expect some conserved sites to be involved in these processes, in view of the fact that membrane fusion is an essential step for coronavirus infection of target cells. Taking membrane fusion as our focal point, this review will systematically describe broad-spectrum coronavirus fusion inhibitors, along with a discussion of their advantages and disadvantages.

(a)

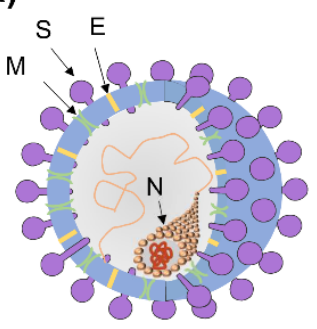

(b)

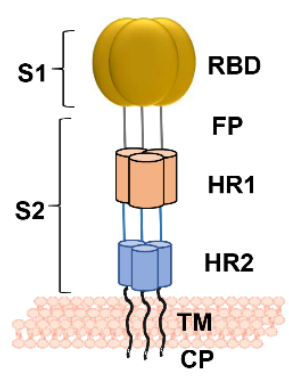

(d)

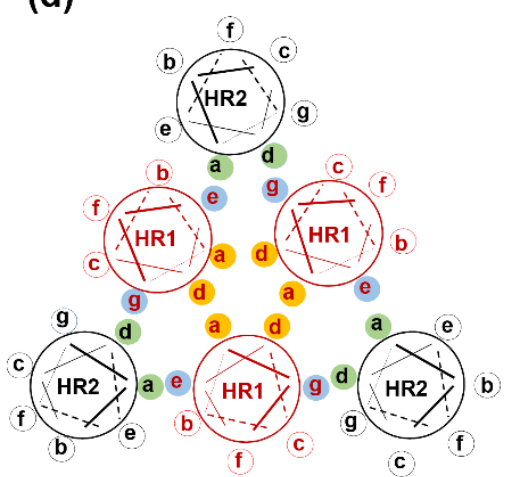

(c)

\begin{tabular}{|l|l|l|l|l|l|l|l|l|l|}
\cline { 2 - 7 } \multicolumn{1}{c|}{ S1 subunit } & \multicolumn{5}{c|}{ S2 subunit } \\
\hline SP & NTD & RBD & & & FP & HR1 & HR2 & TM & CP \\
\hline
\end{tabular}

Figure 1. The spike protein of coronavirus and model of membrane fusion mechanism. (a) Cartoon figure of coronavirus structural protein. Three transmembrane proteins, spike protein (S; purple), membrane protein ( $\mathrm{M}$; green), envelop protein (E; yellow) are found on the surface of the coronavirus envelope. The nucleocapsid protein $(\mathrm{N}$; orange) encapsulates the viral genome inside the virion. (b) Structure of the Spike protein. S protein contains two subunits, S1 and S2. S1 includes the receptor-binding domain (RBD; dark yellow). S2 includes the HR1 region (light orange) and the HR2 region (light blue). (c) The genomic region of complete coronavirus. (d) Interaction between HR1 and HR2. Residues located at the "a" and "d" positions in HR1 helices (shown as yellow circle shadow) interact to form an internal trimer; residues at " $\mathrm{e}$ " and " $\mathrm{g}$ " positions (blue shadow) interact with the residues at the "a" and "d" positions (green shadow) in the HR2 helices to form 6-HB. 


\section{The Mechanism of Membrane Fusion}

\subsection{Receptor Recognition and Binding}

Receptor recognition by the S1 subunit of the spike protein of coronaviruses is the first step of viral infection [15], followed by RBD binding to the receptors. SARS-CoV-2 and SARS-CoV use angiotensin-converting enzyme 2 (ACE2) as a receptor to mediate viral entry into target cells [12]. A study reported that the affinity of the ectodomain of SARS-CoV-2 S protein to ACE2 is 10- to 20-fold higher than that of SARS-CoV S protein [16]. However, another team revealed a similar ACE2 binding affinity between SARS-CoV-2 and SARS-CoV [17]. During the SARS-CoV infection, its spike protein could induce the down-regulation of ACE2 [18], while SARS-CoV-2 might share a similar mechanism to regulate ACE2 expression. Additionally, in COVID-19 patients, not all ACE2-expressing organs had similar level of pathophysiology, implying that some other mechanisms might also mediate the tissue damage; thus, further studies on the interaction between SARS-CoV-2 and ACE2 are warranted [19]. ACE2 is also the receptor of HCoV-NL63 [20]. HCoV-229E uses aminopeptidase N (APN) for cell entry [21], whereas MERS-CoV utilizes dipeptidyl peptidase 4 (DPP4, CD26) as its receptor [22], indicating the diversity of receptors among human coronaviruses. It is the interaction between RBD and the receptor that determines viral infection spectrum and host range [23]. Among the different genera, coronaviruses share low similarity in RBD sequence [24], which might explain the use of different receptors. The amino acid sequence in RBD of SARS-CoV-2 shares $~ 73 \%$ similarity with SARS-CoV and SARSr-CoVs (e.g., WIV1 and Rs3367), respectively, while it only has a $21 \%$ similarity with that of MERS-CoV [25]. Importantly, the RBD contains several neutralization epitopes that can serve as a target for the development of vaccines and antibodies [26-29]. At the same time, variation in the RBD limits the broad-spectrum property of vaccines and antibodies. Nonetheless, it is still possible to utilize the relatively conserved neutralization epitopes among the SARS-CoV and SARS-CoV-2, for research and development of broad-spectrum neutralizing antibodies, against lineage B $\beta$-CoVs, including SARS-CoV-2, SARS-CoV, and SARSr-CoVs.

\subsection{Proteolytic Function in Membrane Fusion}

In the natural state, $S$ protein on the surface of coronavirus is inactive. Only after receptor binding and $S$ protein priming by proteolysis of proteases is the $S$ protein activated and fusion triggered [30]. The S2 subunit is then exposed to mediate membrane fusion. In all coronaviruses, a site called $\mathrm{S}^{\prime}$ that is located upstream of the fusion peptide (FP) of the $\mathrm{S}$ protein, can be cleaved by the host protease [31,32]. At the boundary of the S1/S2 subunits, a study found that SARS-CoV-2 S protein contains a furin cleavage site that is cleaved during biosynthesis, which is different from SARS-CoV and SARSr-CoVs [17] but is similar to MERS-CoV [33]. The virus can enter into the target cell through two routes-direct fusion on the cellular surface and endocytosis. For the endocytosis route, the virus is encapsulated by the endosome after receptor binding. Then, the low $\mathrm{pH}$ environment promotes the cleavage of the $\mathrm{S}$ protein with $\mathrm{pH}$-dependent cysteine protease cathepsin $\mathrm{L}$ (CPL). For direct fusion on the cellular membrane, transmembrane protease serine 2 (TMPRSS2) plays roles in cleavage and activation [34]. Some studies reported that SARS-CoV S protein could also be cleaved with human airway trypsin-like protease [34-36]. TMPRSS2 can also promote MERS-CoV entry into the target cell through the endocytosis pathway [37]. A recent study demonstrated that SARS-CoV-2 utilizes TMPRSS2 to activate the S protein and that a protease inhibitor could inhibit pseudovirus entry [38]. These studies suggest that coronaviruses have a similar proteolytic process and use the same protease, such as TMPRSS2. Therefore, suppressing the proteolysis of proteases might be a path toward the development of broad-spectrum fusion inhibitors.

\subsection{Mechanism of S2 Subunit-Mediated Membrane Fusion}

For coronaviruses, the $\mathrm{S}$ protein binding of receptor initially activates the entry process, resulting in membrane fusion and ensuring virus infection of the target cell. This mechanism was confirmed 
in SARS-CoV and MERS-CoV [39,40]. After RBD binds to cellular receptors, the conformation of S2 subunits changes, followed by exposure of the fusion peptide into the cell membrane. S2 also includes the HR1 and HR2 regions that interact. Residues located at the "a" and " $\mathrm{d}$ " positions in the HR1 helices interact to form an internal trimer, and residues at the " $\mathrm{e}$ " and " $\mathrm{g}$ " positions interact with the residues at the "a" and " $\mathrm{d}$ " positions in the HR2 helices to form a six-helix bundle (6-HB) (Figure 1d). The 6-HB helps the viral membrane and cell membrane to come into close contact for viral fusion and entry.

In native conformation, the S2 subunit is buried inside the S1 subunit and only when fusion occurs, the S2 subunit is instantly exposed. Through sequence alignment, Xia et al. found that the S2 subunit of SARS-CoV-2 is highly conserved, in which the HR1 and HR2 domains share a $92.6 \%$ and $100 \%$ identity with those of SARS-CoV, respectively [41]. They designed two peptides derived from the HR1 and HR2 domains, 2019-nCoV-HR1P and 2019-nCoV-HR2P, respectively, and confirmed that they could interact with each other to form the coiled-coil complex, as shown by using native electrophoresis and circular dichroism. Through crystallographic analysis, the parallel trimeric coiled-coiled center formed by three HR1 domains was surrounded by three HR2 domains, in an antiparallel manner [34]. Thus, SARS-CoV-2 enters the target cell through membrane fusion in a 6-HB-dependent manner.

Therefore, coronaviruses appear to have a similar mechanism of membrane fusion, while HR1 and HR2 regions are highly conserved and can serve as important targets for development of broad-spectrum coronavirus fusion inhibitor-based drugs, for the treatment and prevention of coronavirus diseases.

\section{Broad-Spectrum Coronavirus Fusion Inhibitors}

In this section, we summarize the broad-spectrum coronavirus fusion inhibitors targeting RBD in the S1 subunit of coronavirus S protein, the fusion-related proteases, and the HR1 domain in the S2 subunit of coronavirus $S$ protein, respectively, under development (Figure 2).

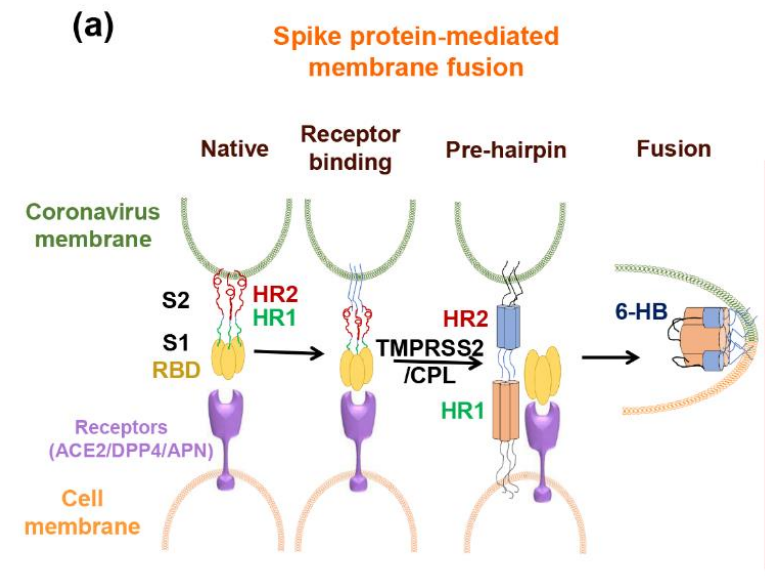

(b)

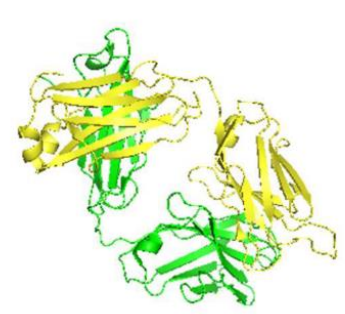

Fab (CR3022) (c)

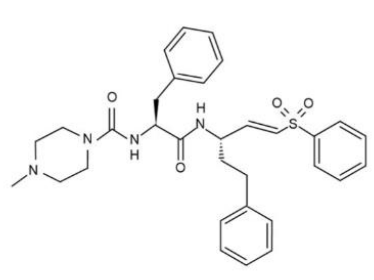

Compound (K11777)

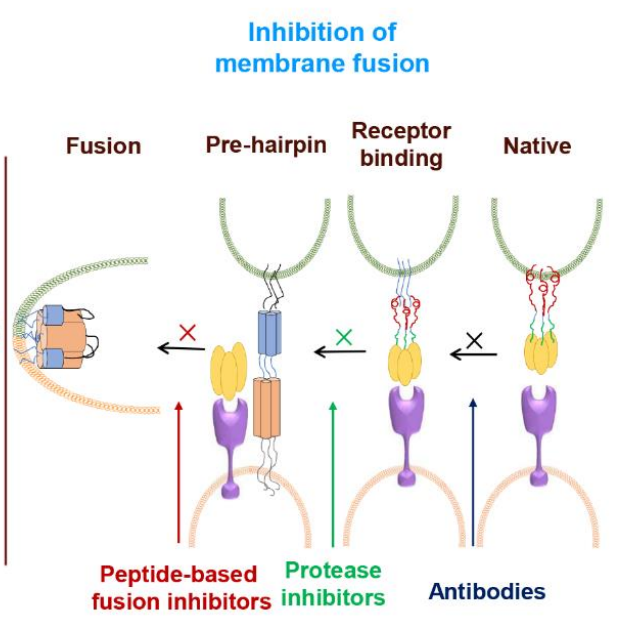

(d)

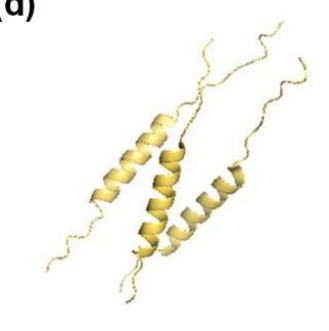

Peptide-based pan-coronavirus fusion inhibitor (EK1)

Figure 2. Model of spike protein (S)-mediated membrane fusion and mechanism of inhibition of membrane fusion with drugs. (a) In the native state, the S1 subunit encapsulates the S2 subunit. After receptor binding, the S2 subunit is exposed, and the fusion peptide inserts into the target cell membrane. Then, 
3-HR1 interacts with 3-HR2 to form the 6-HB structure, followed by membrane fusion. Antibodies block the receptor recognition. Protease inhibitors against TMPRSS2/CPL shuts down S protein priming. Peptide fusion inhibitor binds to the HR1 region, inhibiting the formation of 6-HB. (b-d) The structures of a representative neutralizing antibody (IgG Fab of CR3022), a small molecule inhibitory compound (K11777) and a peptide-based pan-coronavirus fusion inhibitor (EK1).

\subsection{Broad-Spectrum Coronavirus Fusion Inhibitors Targeting RBD}

Fusion inhibitors include antibodies, small molecules, and peptide inhibitors [39,40,42-45]. In this part, we review antibodies and small molecules with broad-spectrum activity targeting RBD in the S1 subunit of coronavirus $S$ protein.

Several specific antibodies targeting $\mathrm{S}$ protein for coronavirus were reported, such as SARS-CoV neutralizing antibodies CR3022, m396, and S109.8 [46,47], MERS-CoV neutralizing antibodies m336 [48] and SAB-301 [48,49], and SARS-CoV-2 antibodies 31B5 and 32D4 [50], but no broad-spectrum coronavirus antibody was reported. Some antibodies were shown to have cross-reactivity among some coronaviruses [51,52]. One study demonstrated that a SARS-CoV-specific monoclonal antibody $(\mathrm{mAb}), \mathrm{CR} 3022$, showed cross-reactive binding to SARS-CoV-2 RBD, but its targeting epitope did not overlap the ACE2 binding site [53]. Sera from convalescent SARS patients showed cross-activity in blocking SARS-CoV-2 pseudovirus entry [38]. Recombinant ACE2-Ig fusion protein exhibited neutralizing activity on pseudotyped SARS-CoV-2 and SARS-CoV, both of which utilized ACE2 as their receptor, with inhibitory concentration $\left(\mathrm{IC}_{50}\right)$ values of 0.1 and $0.8 \mu \mathrm{g} / \mathrm{mL}$, respectively (Table 1 ). It inhibited SARS-CoV-2 and SARS-CoV S-mediated cell-cell fusion with the $\mathrm{IC}_{50}$ of 0.65 and $0.85 \mu \mathrm{g} / \mathrm{mL}$, respectively [54]. Some studies showed that ACE2 negatively regulated the renin-angiotensin system (RAS), and ACE2 and the angiotensin II receptor (AT2) could reduce mouse lung damage induced by sepsis or acid aspiration [55]. Coronavirus down-regulated ACE2 and resveratrol (RES), which experimentally deactivated the RAS system, resulting in an increase of ACE2 [56]. These studies revealed that more attention should be paid to the role of ACE2 in coronavirus infection in the development of putative therapeutic measures. Another study showed that SARS-CoV RBD protein-immunized mouse serum cross-neutralized with SARS-CoV-2, but that MERS-CoV RBD-specific polyclonal antibody had no cross-reactivity [52]. A recent study reported a cross-neutralizing human antibody, 47D11, which could bind to full-length spike protein expressed on cells (Table 1). The antibody targets a conserved epitope in the RBD region. It could inhibit pseudotyped SARS-CoV and SARS-CoV-2 infection of Vero E6 cells with the $\mathrm{IC}_{50}$ values of 0.06 and $0.08 \mu \mathrm{g} / \mathrm{mL}$, respectively. 47D11 could also inhibit live SARS-CoV and SARS-CoV-2 infection with the $\mathrm{IC}_{50}$ of 0.19 and $0.57 \mu \mathrm{g} / \mathrm{mL}$, respectively, through the plaque reduction neutralization test (PRNT) assay. At a concentration of $20 \mu \mathrm{g} / \mathrm{mL}$, the cell-cell fusion mediated by SARS-CoV-S and SARS-CoV-2 $S$ could be inhibited, whereas it could not inhibit fusion mediated by MERS-CoV S protein. However, a mechanism that is not dependent on receptor binding interference, remains unknown [51]. Pseudotyped SARS-CoV- and MERS-CoV-immunized mouse serum was demonstrated to have no inhibitory activity against SARS-CoV-2 infection [25]. The lack of efficacy for these MERS-CoV antibodies could be attributed to the difference in RBD and receptors between SARS-CoV and SARS-CoV-2. No cross-antibodies against MERS-CoV, SARS-COV, and SARS-CoV-2 were found. This revealed the shortcomings in antibodies compared to peptides in achieving broad-spectrum coronavirus cross-neutralizing activity. 
Table 1. Summary of broad-spectrum coronavirus fusion inhibitors targeting receptor-binding domain (RBD).

\begin{tabular}{|c|c|c|c|c|c|c|c|c|}
\hline \multirow[b]{2}{*}{ Inhibitor Name } & \multirow{2}{*}{$\begin{array}{l}\text { Molecular } \\
\text { Weight }\end{array}$} & \multirow[b]{2}{*}{ Target Site } & \multirow[b]{2}{*}{ Testing Model } & \multicolumn{3}{|c|}{ Activity In Vitro $\left(\mathrm{IC}_{50}\right)$} & \multirow{2}{*}{$\begin{array}{l}\text { Activity In Vivo } \\
\text { (Protect Rate) }\end{array}$} & \multirow[b]{2}{*}{ Ref. } \\
\hline & & & & Cell-Cell Fusion & $\begin{array}{l}\text { Pseudovirus } \\
\text { Infection }\end{array}$ & $\begin{array}{l}\text { Live Virus } \\
\text { Infection }\end{array}$ & & \\
\hline ACE2-Ig & $\begin{array}{l}111.38 \mathrm{KD} \\
\text { (protein) }\end{array}$ & ACE2 & $\begin{array}{c}\text { In vitro } \\
\text { 293T/ACE2 cell }\end{array}$ & $\begin{array}{c}0.8 \mu \mathrm{g} / \mathrm{mL} \text { (SARS-CoV) } \\
0.1 \mu \mathrm{g} / \mathrm{mL} \text { (SARS-CoV-2) }\end{array}$ & $\begin{array}{c}0.85 \mu \mathrm{g} / \mathrm{mL} \\
(\mathrm{SARS}-\mathrm{CoV}) \\
0.65 \mu \mathrm{g} / \mathrm{mL} \\
(\mathrm{SARS}-\mathrm{CoV}-2)\end{array}$ & No reported & No reported & {$[54]$} \\
\hline 47D11 & $\begin{array}{l}150 \mathrm{KD} \\
\text { (antibody) }\end{array}$ & RBD & $\begin{array}{l}\text { In vitro } \\
\text { Vero E6 cell }\end{array}$ & $\begin{array}{c}20 \mu \mathrm{g} / \mathrm{mL} \text { (significantly } \\
\text { inhibit, SARS-CoV) } \\
20 \mu \mathrm{g} / \mathrm{mL} \text { (significantly } \\
\text { inhibit, SARS-CoV-2) }\end{array}$ & $\begin{array}{c}0.06 \mu \mathrm{g} / \mathrm{mL} \\
(\mathrm{SARS}-\mathrm{CoV}) \\
0.08 \mu \mathrm{g} / \mathrm{mL} \\
(\mathrm{SARS}-\mathrm{CoV}-2)\end{array}$ & $\begin{array}{c}0.19 \mu \mathrm{g} / \mathrm{mL} \\
(\mathrm{SARS}-\mathrm{CoV}) \\
0.57 \mu \mathrm{g} / \mathrm{mL} \\
(\mathrm{SARS}-\mathrm{CoV}-2)\end{array}$ & No reported & [51] \\
\hline
\end{tabular}


Some small molecules also showed antiviral activity, such as ACE2 inhibitors [43] and interferon-inducible transmembrane (IFITM) proteins [57]. N-(2-aminoethyl)-1 aziridine-ethanamine, a novel ACE2 inhibitor, could inhibit the activity of ACE2 with an $\mathrm{IC}_{50}$ value of $57 \pm 7 \mu \mathrm{M}$, and could block the SARS-CoV S protein-mediated membrane fusion, with a concentration in the micromolar range [43]. However, it might only have efficacy on coronavirus using ACE2 as a receptor and, hence, is difficult to achieve the goal of a broad-spectrum anti-coronavirus drug. IFITM can inhibit host cell entry of several enveloped viruses by promoting the accumulation of cholesterol in endosomes. It could inhibit the entry of MERS-CoV, SARS-CoV, HCoV-229E, and HCoV-NL63, but it is not a specific inhibitor for coronavirus [57]. Thus, small molecules that block receptor binding need further research.

\subsection{Fusion Inhibitors Targeting Fusion-Related Proteases}

At present, research on protease inhibitors mainly focuses on small molecules. Recent studies reported that protease inhibitors could block SARS-CoV-2 entry by inhibiting TMPRSS2 [38]. Some studies detected the ability of protease inhibitors to prevent SARS-CoV-2 infection of cells (Table 2). Camostat mesylate, a clinical drug used for chronic pancreatitis in Japan, could suppress TMPRSS2 activity. It could inhibit Calu-3 cell infection with pseudotyped SARS-CoV-2 with the $\mathrm{EC}_{50}$ (concentration for $50 \%$ of maximal effect) value of about $1 \mu \mathrm{M}$ and $\mathrm{EC}_{90}$ (concentration for $50 \%$ of maximal effect) value of about $5 \mu \mathrm{M}$ [38]. At a concentration of $50 \mu \mathrm{M}$, it could inhibit $80 \%$ pseudotyped SARS-CoV-2 entry into primary human airway epithelial cells [38]. Camostat mesylate also showed inhibitory activity on SARS-CoV-S- and MERS-CoV-S-mediated entry [38,58,59]. Nafamostat mesylate (NM), consistent with camostat mesylate, could inhibit SARS-CoV-2 infection of calu-3 cells [60]. In another study, the $\mathrm{EC}_{50}$ of camostat mesylate against SARS-CoV-2 S-mediated entry into calu-3 cells was $87 \mathrm{nM}$. The activity of nafamostat mesylate was about 15 -fold greater than that of camostat mesylate, with $\mathrm{EC}_{50}$ of $5 \mathrm{nM}$. Moreover, it could inhibit TMPRSS2-dependent host cell entry of pseudotyped SARS-COV and MERS-CoV, with $\mathrm{IC}_{50}$ values of 1.4 and $5.9 \mathrm{nM}$, respectively [60]. In addition, nafamostat mesylate could inhibit MERS-CoV S-mediated membrane fusion with an $\mathrm{IC}_{50}$ value of $100 \mathrm{nM}$, whereas the $\mathrm{IC}_{50}$ of camostat mesylate was $1000 \mathrm{nM}$ [61]. NM was more efficient in reducing MERS-CoV RNA internalization at a concentration of $1 \mathrm{nM}$ [61]. However, gabexate mesylate (FOY), another protease inhibitor, only slightly inhibited SARS-CoV- and SARS-CoV-2 S-mediated entry into calu-3 cells, with EC 50 of $115 \mu \mathrm{M}$ and 1.2 M, respectively, but had no effect on MERS-CoV infection [60].

Besides the TMPRSS2 inhibitors, it was reported that K11777, a small molecule compound-based cathepsin-L like protease inhibitor [62] could inhibit infection of the pseudotyped SARS-CoV, MERS-CoV, HCoV-229E, and HCoV-NL63, with the $\mathrm{IC}_{50}$ values of $0.68,46.12,1.48$, and $6.78 \mathrm{nM}$, respectively, and could block live SARS-CoV replication in Vero 76 cells. However, K11777 could fully inhibit virus entry only in cells lacking activating serine protease. Otherwise, K11777 should combine with serine protease inhibitor, for example, camostat and nafamostat. The derivates of K11777, SMDC256159, and SMDC256160, had similar antiviral effects in vitro. In SARS-CoV lethal infection mouse model, single usage of SMDC256160 exhibited no significant protection, while camostat could protect about $60 \%$ mice from death [63]. The in vivo efficiency of these protease inhibitors have not yet been reported. Another cathepsin L inhibitor, SID-26681509 at $2 \mu \mathrm{M}$ could inhibit 76\% SARS-CoV-2 S pseudovirions for entry into 293/hACE2 cells [64]. Teicoplanin, a glycopeptide antibiotic, could potently inhibit CPL in the late endosome/lysosome; thus, blocking the entry of coronavirus. It inhibited pseudotyped MERS-CoV and SARS-CoV entry with the $\mathrm{IC}_{50}$ values of 630 and $3760 \mathrm{nM}$, respectively [65]. Recently, a study showed that teicoplanin inhibits pseudotyped SARS-CoV-2 entry with an $\mathrm{IC}_{50}$ value of $1660 \mathrm{nM}$. Other glycopeptide antibiotics, dalbavancin, also exhibited inhibitory activity, but vancomycin did not block the entry of SARS-CoV-2 [66]. Additionally, a broad-spectrum cysteine protease inhibitor E64D at $30 \mu \mathrm{M}$ could inhibit $92.5 \%$ SARS-CoV-2 pseudovirions for entry [64]. However, the $50 \%$ cell cytotoxicity concentration $\left(\mathrm{CC}_{50}\right)$ of some small molecules were never reported. To evaluate whether the small molecules could be developed as a broad-spectrum coronavirus fusion-inhibitor-based drug, its safety and bioactivity in vivo needs to be assessed. 
Table 2. Summary of fusion inhibitors targeting fusion-related proteases.

\begin{tabular}{|c|c|c|c|c|c|c|c|c|}
\hline \multirow{2}{*}{ Inhibitor Name } & \multirow{2}{*}{$\begin{array}{c}\text { Molecular } \\
\text { Weight }\end{array}$} & \multirow{2}{*}{ Target Site } & \multirow{2}{*}{ Testing Model } & \multicolumn{3}{|c|}{ Activity In Vitro $\left(\mathrm{IC}_{50}\right)$} & \multirow{2}{*}{$\begin{array}{c}\text { Activity In } \\
\text { Vivo } \\
\text { (Protect Rate) }\end{array}$} & \multirow{2}{*}{ Ref. } \\
\hline & & & & Cell-Cell Fusion & Pseudovirus Infection & Live Virus Infection & & \\
\hline $\begin{array}{l}\text { Camostat } \\
\text { mesylate }\end{array}$ & $\begin{array}{c}494.52 \\
\text { (compound) }\end{array}$ & TMPRSS2 & $\begin{array}{c}\text { In vitro: Calu-3; } \\
\text { 293FT; } \\
\text { Vero/TMPRSS2 cell } \\
\text { In vivo: } \\
\text { BALB/c mice }\end{array}$ & $\begin{array}{c}\text { About } 100 \mathrm{nM} \\
\text { (MERS-CoV, 293FT } \\
\text { cell) }\end{array}$ & $\begin{array}{l}444 \mathrm{nM} \text { (MERS-CoV) } \\
198 \mathrm{nM} \text { (SARS-CoV) } \\
87 \mathrm{nM} \text { (SARS-CoV-2) }\end{array}$ & $\begin{array}{c}\text { About } 100 \mathrm{nM} \\
\text { (significantly inhibit, } \\
\text { MERS-CoV) }\end{array}$ & $\begin{array}{c}\sim 60 \% \\
\text { (SARS-CoV } \\
\text { lethal model) }\end{array}$ & {$[60,61,63]$} \\
\hline $\begin{array}{l}\text { Nafamostat } \\
\text { mesylate }\end{array}$ & $\begin{array}{c}539.58 \\
\text { (compound) }\end{array}$ & TMPRSS2 & $\begin{array}{c}\text { In vitro: Caclu-3 } \\
\text { 293FT; } \\
\text { Vero/TMPRSS2 cell }\end{array}$ & $\begin{array}{c}100 \mathrm{nM} \text { (MERS-CoV, } \\
\text { 293FT cell) } \\
1 \mathrm{nM} \\
\text { (MERS-CoV, calu-3 } \\
\text { cell) } \\
\end{array}$ & $\begin{array}{l}5.9 \mathrm{nM} \text { (MERS-CoV) } \\
1.4 \mathrm{nM} \text { (SARS-CoV) } \\
5 \mathrm{nM} \text { (SARS-CoV-2) }\end{array}$ & $\begin{array}{l}1 \mathrm{nM} \text { (significantly } \\
\text { inhibit, MERS-CoV) }\end{array}$ & No reported & {$[60,61]$} \\
\hline $\begin{array}{l}\text { Gabexate } \\
\text { mesylate }\end{array}$ & $\begin{array}{c}417.48 \\
\text { (compound) }\end{array}$ & TMPRSS2 & $\begin{array}{c}\text { In vitro: Calu-3 cell } \\
\text { 293FT cell }\end{array}$ & $\begin{array}{c}>1 \times 10^{5} \mathrm{nM} \\
\text { (MERS-CoV, } 293 \mathrm{FT} \\
\text { cell) }\end{array}$ & $\begin{array}{c}1.15 \times 10^{5} \mathrm{nM} \\
(\mathrm{SARS}-\mathrm{CoV}) \\
1.2 \times 10^{9} \mathrm{nM} \\
(\mathrm{SARS}-\mathrm{CoV}-2) \\
\end{array}$ & No reported & No reported & {$[60,61]$} \\
\hline K11777 & $\begin{array}{l}\text { No reported } \\
\text { (compound) }\end{array}$ & CPL & $\begin{array}{c}\text { In vitro: } 293 \mathrm{~T} / \mathrm{ACE} 2 \\
293 \mathrm{~T} / \mathrm{CD} 13 \\
\text { Vero cells } \\
\text { Vero } 76 \text { cells } \\
\end{array}$ & No reported & $\begin{array}{c}0.68 \mathrm{nM} \text { (SARS-CoV) } \\
1.48 \mathrm{nM}(\mathrm{HCoV}-229 \mathrm{E}) \\
6.78 \mathrm{nM} \text { (HCoV-NL63) } \\
46.12 \mathrm{nM} \text { (MERS-CoV) }\end{array}$ & $\begin{array}{c}<0.05 \mathrm{nM} \\
(\text { SARS-CoV) }\end{array}$ & No reported & [63] \\
\hline
\end{tabular}




\subsection{Broad-Spectrum Coronavirus Fusion Inhibitors Targeting the HR1 Domain}

Currently, research on fusion inhibitors is mainly focused on peptide drugs. Researchers have discovered many peptides that can inhibit coronavirus infections, such as CP1 derived from SARS-CoV HR2 [39], MERS-HR2P derived from MERS-CoV HR2 [40], and 2019-nCoV-HR2P derived from SARS-CoV-2 HR2 [41]. Recently, we reported some pan-coronavirus (pan-CoV) peptide fusion inhibitors. These peptide fusion inhibitors, including OC43-HR2P, EK1, and EK1C4 [34,44], inhibit human coronavirus fusion by targeting the HR1 domain, as shown in Table 1. OC43-HR2P could inhibit MERS-CoV-, SARS-CoV-, and HCoV-OC43 S-mediated cell-cell fusion with $\mathrm{IC}_{50}$ values of $0.39,0.54$, and $0.66 \mu \mathrm{M}$, respectively. It also showed an effective inhibitory activity against 229E- and NL63 S-mediated cell-cell fusion with $\mathrm{IC}_{50}$ of 0.84 and $0.94 \mu \mathrm{M}$, respectively [44]. By introducing the negatively and positively charged amino acids Glu (E) and Lys (K), the new peptide EK1 was obtained. EK1 peptide also targeted the HR1 domain and shared a mechanism of action in common with other peptide fusion inhibitors, including SJ-2176 [67], CP-1 [39], and MERS-HR2P [40]. EK1 blocks the fusion of viral and target cell membranes and entry into the target cell by competitively inhibiting the formation of 6-HB. Extensive hydrophobic interactions in EK1 and hCoVs HR1 guaranteed the broad-spectrum neutralization of EK1. EK1 peptide had broad-spectrum antiviral activity against five human coronaviruses (pseudotyped SARS-CoV, MERS-CoV, 229E, OC43, and NL63) and three bat-SARSr-CoVs (pseudotyped Rs3367, WIV1, SHC014) in vitro, with $\mathrm{IC}_{50}$ values ranging from 0.26 to $6.02 \mu \mathrm{M}$. Moreover, the pan-CoVs fusion inhibitor EK1 also had a preventive and protective effect in vivo. It could protect hDPP4-transgenic mice, or regular mice, from HCoV-OC43 or MERS-CoV infection via the intranasal route [44]. The structural basis of broad-spectrum inhibitory activity is that EK1 can snugly insert into the hydrophobic groove formed by HR1 and then deliver a 6-HB architecture similar to that of 3HR1-3HR2 6-HB, thus blocking virus infection. The hydrophobic, chain-to-side chain hydrophilic interactions and ridge-packing interactions between the EK1 and 3HR1 cores ensure the pan-CoV's inhibitory activity [44].

Although the HR1 region of 2019-nCoV has about a 38\% difference from that of SARS-CoV, the EK1 peptide could still bind to the 2019-nCoV-HR1P, inhibit S-mediated cell-cell fusion with $\mathrm{IC}_{50}$ of $0.19 \mu \mathrm{M}$, and could significantly inhibit pseudotyped SARS-CoV-2 entry with an $\mathrm{IC}_{50}$ value of $2.38 \mu \mathrm{M}$ [41].

EK1 peptide was conjugated with cholesterol at its C-terminus. The resultant lipopeptide EK1C4 exhibited significantly enhanced anti-CoV activity, about 150- and 240-fold over that of EK1 peptide against pseudotyped SARS-CoV-2 infection and S-mediated membrane fusion [34]. Most importantly, EK1C4 could inhibit infection of live HCoVs, including SARS-CoV-2, MERS-CoV, HCoV-NL63, $\mathrm{HCoV}-229 \mathrm{E}$, and $\mathrm{HCoV}-\mathrm{OC} 43$, with $\mathrm{IC}_{50}$ values ranging from 4 to $188 \mathrm{nM}$ (Table 3). To evaluate the potential prophylactic effect, the authors utilized EK1C4 to treat HCoV-OC43-infected newborn mice, before or after infection. They found that the mice treated with EK1C4 at 0.5, 2, and $4 \mathrm{~h}$ before the virus infection all lived, while mortality of mice in the pre-2-h group treated with the EK1 peptide was similar to the viral control group [34]. These results suggested that the antiviral activity of EK1C4 was higher than that of the EK1 peptide. Results from the experiments with both EK1 and EK1C4 highlighted that the peptide fusion inhibitors did have the potential for development as promising antiviral agents. 
Table 3. Summary of the broad-spectrum coronavirus fusion inhibitors targeting the HR1 domain.

\begin{tabular}{|c|c|c|c|c|c|c|c|c|}
\hline \multirow{2}{*}{ Inhibitor Name } & \multirow{2}{*}{$\begin{array}{l}\text { Molecular } \\
\text { Weight }\end{array}$} & \multirow{2}{*}{ Target Site } & \multirow{2}{*}{ Testing Model } & \multicolumn{3}{|c|}{ Activity In Vitro $\left(\mathrm{IC}_{50}\right)$} & \multirow{2}{*}{$\begin{array}{l}\text { Activity In Vivo } \\
\text { (Protect Rate) }\end{array}$} & \multirow{2}{*}{ Ref. } \\
\hline & & & & Cell-Cell Fusion & Pseudovirus Infection & Live Virus Infection & & \\
\hline OC43-HR2P & $\begin{array}{l}4270.86 \\
\text { (peptide) }\end{array}$ & HR1 & $\begin{array}{l}\text { In vitro } \\
\text { Huh-7 cells }\end{array}$ & $\begin{array}{c}390 \mathrm{nM} \text { (MERS-CoV) } \\
540 \mathrm{nM} \text { (SARS-CoV) } \\
660 \mathrm{nM} \text { (HCoV-OC43) } \\
840 \mathrm{nM} \text { (HCoV-229E) } \\
940 \mathrm{nM} \text { (HCoV-NL63) }\end{array}$ & $\begin{array}{c}\text { Similar to EK1 } \\
\text { (1810 nM, HCoV-OC43)) }\end{array}$ & 930 nM (HCoV-OC43) & No reported & [44] \\
\hline EK1 & $\begin{array}{c}4331.98 \\
\text { (peptide) }\end{array}$ & HR1 & $\begin{array}{c}\text { In vitro } \\
\text { Huh-7 cells } \\
\text { 293T/ACE2 cells } \\
\text { In vivo } \\
\text { Balb/c mice }\end{array}$ & $\begin{array}{c}315 \mathrm{nM} \text { (SARS-CoV-2) } \\
180 \mathrm{nM} \text { (MERS-CoV) } \\
270 \mathrm{nM} \text { (SARS-CoV) } \\
330 \mathrm{nM} \text { (HCoV-OC43) } \\
150 \mathrm{nM} \text { (HCoV-229E) } \\
630 \mathrm{nM} \text { (HCoV-NL63) }\end{array}$ & $\begin{array}{c}2375 \mathrm{nM} \text { (SARS-CoV-2) } \\
260 \mathrm{nM} \text { (MERS-CoV) } \\
2230 \mathrm{MM} \text { (SARS-CoV) } \\
3350 \mathrm{nM} \text { (HCoV-229E) } \\
6020 \mathrm{nM} \text { (HCoV-NL63) } \\
1810 \mathrm{nM} \text { (HCoV-OC43) } \\
2250 \mathrm{nM} \text { (Rs 3367) } \\
2010 \mathrm{nM} \text { (WIVI) }\end{array}$ & $\begin{array}{c}2468 \mathrm{nM} \text { (SARS-CoV-2) } \\
110 \mathrm{nM} \text { (MERS-CoV) } \\
620 \mathrm{nM} \text { (HCoV-OC43) } \\
690 \mathrm{nM}(\mathrm{HCoV}-229 \mathrm{E}) \\
480 \mathrm{nM} \text { (HCoV-NL63) }\end{array}$ & $\begin{array}{c}100 \% \\
\text { (prophylactic; } 0.5 \mathrm{~h} \\
\text { pre-infection) } \\
66.7 \% \\
\text { (therapeutic; } 0.5 \mathrm{~h} \\
\text { post-infection) }\end{array}$ & {$[34,44]$} \\
\hline EK1C4 & $\begin{array}{c}5436.08 \\
\text { (lipopeptide) }\end{array}$ & HR1 & $\begin{array}{c}\text { In vitro } \\
\text { Huh-7 cells } \\
\text { 293T/ACE2 cells } \\
\text { In vivo } \\
\text { Balb/c mice }\end{array}$ & $\begin{array}{c}1.3 \mathrm{nM} \text { (SARS-CoV-2) } \\
4.3 \mathrm{nM} \text { (SARS-CoV) } \\
2.5 \mathrm{nM} \text { (MERS-CoV) } \\
7.7 \mathrm{nM} \text { (HCoV-OC43) } \\
5.2 \mathrm{nM} \text { (HCoV-229E) } \\
21.4 \mathrm{nM} \text { (HCoV-NL63) } \\
4.5 \mathrm{nM} \text { (WIVI) } \\
8.1 \mathrm{nM} \text { (Rs 3367) } \\
4.3 \mathrm{nM} \text { (SHC014) }\end{array}$ & $\begin{array}{c}15.8 \mathrm{nM} \text { (SARS-CoV-2) } \\
11.7 \mathrm{nM} \text { (SARS-CoV) } \\
11.1 \mathrm{nM} \text { (MERS-CoV) } \\
37.7 \mathrm{nM} \text { (HCoV-OC43) } \\
12.4 \mathrm{nM} \text { (HCoV-229E) } \\
76.6 \mathrm{nM} \text { (HCoV-NL63) } \\
30.8 \mathrm{nM} \text { (WIVI) } \\
66.9 \mathrm{nM} \text { (Rs 3367) }\end{array}$ & $\begin{array}{c}36.5 \mathrm{nM} \text { (SARS-CoV-2) } \\
4.2 \mathrm{nM} \text { (MERS-CoV) } \\
24.8 \mathrm{nM} \text { (HCoV-OC43) } \\
101.5 \mathrm{nM} \text { (HCoV-229E) } \\
187.6 \mathrm{nM} \text { (HCoV-NL63) }\end{array}$ & $\begin{array}{c}100 \% \\
\text { (prophylactic; } 4 \mathrm{~h} \\
\text { pre-infection) } \\
100 \% \\
\text { (therapeutic; } 0.5 \mathrm{~h} \\
\text { post- infection) }\end{array}$ & {$[34,44]$} \\
\hline
\end{tabular}




\section{Advantages and Disadvantages of the Broad-Spectrum Coronavirus Fusion Inhibitors}

Broad-spectrum coronavirus fusion inhibitors have different strengths and weaknesses, and we summarize them in this part.

The main advantages of a human neutralizing antibody include its high safety, stability, and efficacy. However, the highly conserved HR1 region is not a good target for antibody IgG with a molecular weight of $150 \mathrm{kD}$, because a protein with more than $71 \mathrm{kD}$ cannot easily access the HR1-trimer in the fusion-intermediate stage [68,69]. Consequently, antibodies for coronavirus usually target the RBD domain or the S1 subunit, not the HR1 region. RBD is usually considered a promising target for developing specific antibodies [48]. However, there are no reported broad-spectrum neutralizing antibodies against divergent coronaviruses. As described above, mouse antiserum or monoclonal antibody against SASRS-CoV showed cross-reactivity in SARS-CoV-2, and SARSr-CoVs [25,51,52]. Thus, it is still possible to develop broad-spectrum neutralizing antibodies against lineage $B$ betacoronaviruses. However, there are also some disadvantages to antibodies. First, the high cost of antibodies increase the burden on patients. Additionally, treatment with a single antibody could induce escape mutations in RBD, for instance, the MERS-COV antibody CDC2-C2 [70]. Moreover, the RBD is a high mutable region of the coronavirus $S$ protein. As reported in a recent study, mAbs with an epitope of SARS-CoV RBD did not recognize the SARS-CoV-2 RBD region and showed low cross-reactivity to it [16].

Small molecule fusion inhibitors targeting serine protease have some advantages over antibodies. First, they can be administered orally. Second, they can be stored and transported at normal temperature. Third, they are economical to synthesize and easily acceptable by patients. However, proteases are widely present in various tissues and cells; consequently, protease-targeting inhibitors could have side effects and produce toxic responses. One study reported that camostat mesylate caused acute eosinophilic pneumonia [71]. Nafamostat mesylate has a short half-life with risk of bleeding [72]. Moreover, the single-use of SMDC256160 had no protective effect in vivo. Thus, whether protease inhibitor could effectively inhibit coronaviruses infection in vivo still requires more research work.

Pan-CoV peptide fusion inhibitors have numerous advantages. First, the EK1 peptide has low immunogenicity with no detectable EK1-specific antibodies in EK1-immunized mouse serum, over a two-week period [44]. Second, the targeting site of the EK1 peptide is the HR1 domain in the S2 subunit. This region, as noted above, is highly conserved, thus guaranteeing the inhibitory activity of pan-CoVs. Third, since the S2 subunit is instantly exposed, drug resistance is not easily induced. Fourth, EK1 has excellent druggable properties, has good solubility in water, and shows superior stability. Compared to the EK1 peptide, EK1C4 has a more potent inhibitory activity. It can treat $\mathrm{HCoV-OC43-infected} \mathrm{mice} \mathrm{and} \mathrm{protect} \mathrm{mice} \mathrm{from} \mathrm{virus} \mathrm{infections} \mathrm{via} \mathrm{the} \mathrm{intranasal} \mathrm{route} \mathrm{[34,44].} \mathrm{It} \mathrm{can}$ also be administered to patients via inhalation. Moreover, local application is expected to be much safer than systemic administration [34,44]. Generally, peptide drugs are safer than chemical medications because peptide drugs have good specificity and biological activity, a clear mechanism of drug action, and often have fewer side effects [34,44,73]. Therefore, lipopeptide EK1C4 is a promising candidate for development as a pan-CoV fusion inhibitor-based therapeutic and prophylactic for the treatment and prevention of the current COVID-19 and MERS, and future emerging and reemerging coronavirus diseases. EK1C4 can be inhaled as an aerosol formulation to reduce the viral load in the lung, thus alleviating the pulmonary inflammatory reaction and reducing the chance of transmission to high-risk groups. An intranasal formulation of EK1C4 can prevent infection [34]. Different from small molecules, peptide drugs do indeed represent a unique class. For example, peptides have been developed as drugs for infectious disease and cancer treatment, such as the anti-HIV peptide drug T20 approved by the FDA to treat AIDS [74]. Of course, peptide drugs have disadvantages. First, most peptide drugs can only be synthesized, increasing the cost, compared to small molecules. Second, peptide drugs might be more expensive than smaller molecule compound drugs because of the high cost of peptide production. Third, peptide drugs generally have a shorter half-life than antibody drugs [75]. Finally, peptide drugs cannot be taken orally, making them less convenient than small molecules. 


\section{Summary}

The entry processes of a coronavirus include receptor recognition and binding, proteolytic cleavage of S protein, and S2 subunit-mediated membrane fusion. Each of these processes can serve as a target for the development of broad-spectrum drugs. Neutralizing antibodies that generally target the RBD in S protein have the advantages of high safety, stability, and efficacy; but the high variation of the RBD region among coronaviruses limits the development of broad-spectrum neutralizing antibodies. The high cost of production is another negative factor for their clinical applications. The small molecule compound-based entry inhibitors can be taken orally, with high acceptance. However, they are generatelly more toxic and less effective than antibodies and peptides in blocking virus entry through protein-protein interaction. Since many viruses use the proteases to mediate membrane fusion, they can be used as targets for development of broad-spectrum virus fusion inhibitors. However, they are human proteins and have their own functions in human bodies. Therefore, application of an inhibitor of the related enzyme might cause some side-effects. Peptide-based pan-CoV fusion inhibitors have shown great promise in the development of broad-spectrum prophylatics or therapeutics for the prevention and treatment of the current COVID-19, MERS, and other coronavirus diseases, as well as the emerging and reemerging coronavirus diseases that will occur in the future. Their target site, the HR1-trimer at the fusion intermediate state, is accessible to molecules less than $70 \mathrm{Kd}$. Therefore, the antibody is too big $(\sim 150 \mathrm{Kd})$ to access it, while the small molecule compound is too small to block the HR1-HR2 interaction. Moreover, it is safer than small molecule compounds and is more economical than antibodies. The weaknesses of a peptide drug include its short half-life and ability to induce antibodies against the peptide drugs. However, these antiviral peptide drugs are generally used in the early stage of the viral infection for a short period of time (e.g., 2-3 weeks) to save patients' lives. Therefore, these weaknesses might not significantly affect their clinical use.

Author Contributions: X.W. and S.X. wrote the manuscript and depicted the figures. Q.W., W.X. and W.L. verified the data. S.J. and L.L. conceptualized and revised the manuscript. All authors have read and agree to the published version of the manuscript.

Funding: This work was supported by the National Megaprojects of China for Major Infectious Diseases (2018ZX10301403 to L.L.) and the National Natural Science Foundation of China (81822045 to L.L.; 81630090 to S.J.; 81703571 to W.X.).

Conflicts of Interest: The authors declare no conflict of interest. The funders had no role in the design of the study; in the collection, analyses, or interpretation of data; in the writing of the manuscript, or in the decision to publish the results.

$\begin{array}{ll}\text { Abbreviations } & \\ \text { SARS } & \text { Severe acute respiratory syndrome } \\ \text { MERS } & \text { Middle East respiratory syndrome } \\ \text { COVID-19 } & \text { Coronavirus Disease 2019 } \\ \text { SARS-CoV-2 } & \text { SARS coronavirus 2 } \\ \text { 2019-nCoV } & \text { Novel coronavirus 2019 } \\ \text { HCoV-19 } & \text { Human coronavirus 2019 } \\ \text { SARSr-CoV } & \text { SARS-related coronavirus } \\ \text { NTD } & \text { N-terminal domain } \\ \text { CTD } & \text { C-terminal domain } \\ \text { RBD } & \text { Receptor-binding domain } \\ \text { ACE2 } & \text { Angiotensin-converting enzyme 2 } \\ \text { APN } & \text { Aminopeptidase N } \\ \text { DPP4 } & \text { Dipeptidyl peptidase 4 } \\ \text { CPL } & \text { Cysteine protease cathepsin L } \\ \text { TMPRSS2 } & \text { Transmembrane protease serine 2 } \\ \text { FP } & \text { Fusion peptide }\end{array}$




$\begin{array}{ll}\text { 6-HB } & \text { Six-helix bundle } \\ \text { PRNT } & \text { Plaque reduction neutralization test } \\ \text { IFITM } & \text { Interferon-inducible transmembrane } \\ \text { NM } & \text { Nafamostat mesylate } \\ \text { FOY } & \text { Ggabexate mesylate } \\ \text { IC }_{50} & 50 \% \text { inhibitory concentration } \\ \text { CC }_{50} & 50 \% \text { cell cytotoxicity concentration } \\ \text { EC }_{50} & \text { Concentration for } 50 \% \text { of maximal effect } \\ \text { EC } 90 & \text { Concentration for } 90 \% \text { of maximal effect } \\ \text { RAS } & \text { Renin-angiotensin system } \\ \text { AT2 } & \text { Angiotensin II receptor } \\ \text { pan-CoV } & \text { Pan-coronavirus }\end{array}$

\section{References}

1. Coronavirus Disease (COVID-19) Pandemic. Available online: https://www.who.int/ (accessed on 26 April 2020).

2. Jiang, S.; Shi, Z.; Shu, Y.; Song, J.; Gao, G.F.; Tan, W.; Guo, D. A distinct name is needed for the new coronavirus. Lancet 2020, 395, 949. [CrossRef]

3. Coronaviridae Study Group of the International Committee on Taxonomy of Viruses. The species Severe acute respiratory syndrome-related coronavirus: Classifying 2019-nCoV and naming it SARS-CoV-2. Nat. Microbiol. 2020, 5, 536-544. [CrossRef] [PubMed]

4. Jiang, S.; Du, L.; Shi, Z. An emerging coronavirus causing pneumonia outbreak in Wuhan, China: Calling for developing therapeutic and prophylactic strategies. Emerg. Microbes Infect. 2020, 9, 275-277. [CrossRef] [PubMed]

5. Prioritizing Diseases for Research and Development in Emergency Contexts. Available online: https://www. who.int/activities/prioritizing-diseases-for-research-and-development-in-emergency-contexts (accessed on 26 April 2020).

6. Jiang, S.; Shi, Z. The First Disease X Is Caused by a Highly Transmissible Acute Respiratory Syndrome Coronavirus. Virol. Sin. 2020. [CrossRef]

7. De Wit, E.; van Doremalen, N.; Falzarano, D.; Munster, V.J. SARS and MERS: Recent insights into emerging coronaviruses. Nat. Rev. Microbiol. 2016, 14, 523-534. [CrossRef] [PubMed]

8. Middle East Respiratory Syndrome Coronavirus (MERS-CoV). MERS Monthly Summary, November 2019. Available online: https://www.who.int/emergencies/mers-cov/en/ (accessed on 26 April 2020).

9. Coronavirus Disease (COVID-19) Pandemic. Coronavirus Disease (COVID-19) Outbreak Situation. Available online: https://www.who.int/emergencies/diseases/novel-coronavirus-2019 (accessed on 26 April 2020).

10. Cheng, V.C.; Lau, S.K.; Woo, P.C.; Yuen, K.Y. Severe acute respiratory syndrome coronavirus as an agent of emerging and reemerging infection. Clin. Microbiol. Rev. 2007, 20, 660-694. [CrossRef]

11. Chan, J.F.; Lau, S.K.; To, K.K.; Cheng, V.C.; Woo, P.C.; Yuen, K.Y. Middle East Respiratory Syndrome Coronavirus: Another Zoonotic Betacoronavirus Causing SARS-Like Disease. Clin. Microbiol. Rev. 2015, 28, 465-522. [CrossRef]

12. Zhou, P.; Yang, X.; Wang, X.; Hu, B.; Zhang, L.; Zhang, W.; Si, H.; Zhu, Y.; Li, B.; Huang, C.; et al. A pneumonia outbreak associated with a new coronavirus of probable bat origin. Nature 2020, 579, 270-273. [CrossRef]

13. Wu, F.; Zhao, S.; Yu, B.; Chen, Y.M.; Wang, W.; Song, Z.G.; Hu, Y.; Tao, Z.W.; Tian, J.H.; Pei, Y.Y.; et al. A new coronavirus associated with human respiratory disease in China. Nature 2020, 579, 265-269. [CrossRef]

14. Tang, T.; Bidon, M.; Jaimes, J.A.; Whittaker, G.R.; Daniel, S. Coronavirus membrane fusion mechanism offers a potential target for antiviral development. Antivir. Res. 2020, 178, 104792. [CrossRef]

15. Baranowski, E.; Ruiz-Jarabo, C.M.; Domingo, E. Evolution of cell recognition by viruses. Science 2001, 292, 1102-1105. [CrossRef] [PubMed]

16. Wrapp, D.; Wang, N.S.; Corbett, K.S.; Goldsmith, J.A.; Hsieh, C.L.; Abiona, O.; Graham, B.S.; McLellan, J.S. Cryo-EM structure of the 2019-nCoV spike in the prefusion conformation. Science 2020, 367, 1260-1263. [CrossRef] [PubMed]

17. Walls, A.C.; Park, Y.J.; Tortorici, M.A.; Wall, A.; McGuire, A.T.; Veesler, D. Structure, Function, and Antigenicity of the SARS-CoV-2 Spike Glycoprotein. Cell 2020, 181, 281-292 e286. [CrossRef] [PubMed] 
18. Kuba, K.; Imai, Y.; Rao, S.A.; Gao, H.; Guo, F.; Guan, B.; Huan, Y.; Yang, P.; Zhang, Y.L.; Deng, W.; et al. A crucial role of angiotensin converting enzyme 2 (ACE2) in SARS coronavirus-induced lung injury. Nat. Med. 2005, 11, 875-879. [CrossRef] [PubMed]

19. Bourgonje, A.R.; Abdulle, A.E.; Timens, W.; Hillebrands, J.L.; Navis, G.J.; Gordijn, S.J.; Bolling, M.C.; Dijkstra, G.; Voors, A.A.; Osterhaus, A.; et al. Angiotensin-converting enzyme-2 (ACE2), SARS-CoV-2 and pathophysiology of coronavirus disease 2019 (COVID-19). J. Pathol. 2020. [CrossRef]

20. Wu, K.; Li, W.; Peng, G.; Li, F. Crystal structure of NL63 respiratory coronavirus receptor-binding domain complexed with its human receptor. Proc. Natl. Acad. Sci. USA 2009, 106, 19970-19974. [CrossRef]

21. Yeager, C.L.; Ashmun, R.A.; Williams, R.K.; Cardellichio, C.B.; Shapiro, L.H.; Look, A.T.; Holmes, K.V. Human Aminopeptidase-N Is a Receptor for Human Coronavirus-229E. Nature 1992, 357, 420-422. [CrossRef]

22. Raj, V.S.; Mou, H.; Smits, S.L.; Dekkers, D.H.; Muller, M.A.; Dijkman, R.; Muth, D.; Demmers, J.A.; Zaki, A.; Fouchier, R.A.; et al. Dipeptidyl peptidase 4 is a functional receptor for the emerging human coronavirus-EMC. Nature 2013, 495, 251-254. [CrossRef]

23. Li, F. Receptor recognition and cross-species infections of SARS coronavirus. Antivir. Res. 2013, 100, $246-254$. [CrossRef]

24. Li, F. Evidence for a Common Evolutionary Origin of Coronavirus Spike Protein Receptor-Binding Subunits. J. Virol. 2012, 86, 2856-2858. [CrossRef]

25. Liu, Z.; Xia, S.; Wang, X.; Lan, Q.; Xu, W.; Wang, Q.; Jiang, S.; Lu, L. Inefficiency of Sera from Mice Treated with Pseudotyped SARS-CoV to Neutralize 2019-nCoV Infection. Virol. Sin. 2020. [CrossRef] [PubMed]

26. Du, L.; Zhao, G.; Yang, Y.; Qiu, H.; Wang, L.; Kou, Z.; Tao, X.; Yu, H.; Sun, S.; Tseng, C.T.; et al. A Conformation-Dependent Neutralizing Monoclonal Antibody Specifically Targeting Receptor-Binding Domain in Middle East Respiratory Syndrome Coronavirus Spike Protein. J. Virol. 2014, 88, 7045-7053. [CrossRef] [PubMed]

27. He, Y.; Lu, H.; Siddiqui, P.; Zhou, Y.; Jiang, S. Receptor-binding domain of severe acute respiratory syndrome coronavirus spike protein contains multiple conformation-dependent epitopes that induce highly potent neutralizing antibodies. J. Immunol. 2005, 174, 4908-4915. [CrossRef] [PubMed]

28. Sui, J.; Li, W.; Murakami, A.; Tamin, A.; Matthews, L.J.; Wong, S.K.; Moore, M.J.; Tallarico, A.S.; Olurinde, M.; Choe, H.; et al. Potent neutralization of severe acute respiratory syndrome (SARS) coronavirus by a human mAb to S1 protein that blocks receptor association. Proc. Natl. Acad. Sci. USA 2004, 101, 2536-2541. [CrossRef]

29. Du, L.; He, Y.; Zhou, Y.; Liu, S.; Zheng, B.; Jiang, S. The spike protein of SARS-CoV-A target for vaccine and therapeutic development. Nat. Rev. Microbiol. 2009, 7, 226-236. [CrossRef]

30. White, J.M.; Whittaker, G.R. Fusion of Enveloped Viruses in Endosomes. Traffic 2016, 17, 593-614. [CrossRef]

31. Madu, I.G.; Roth, S.L.; Belouzard, S.; Whittaker, G.R. Characterization of a Highly Conserved Domain within the Severe Acute Respiratory Syndrome Coronavirus Spike Protein S2 Domain with Characteristics of a Viral Fusion Peptide. J. Virol. 2009, 83, 7411-7421. [CrossRef]

32. Millet, J.K.; Whittaker, G.R. Host cell proteases: Critical determinants of coronavirus tropism and pathogenesis. Virus Res. 2015, 202, 120-134. [CrossRef]

33. Millet, J.K.; Whittaker, G.R. Host cell entry of Middle East respiratory syndrome coronavirus after two-step, furin-mediated activation of the spike protein. Proc. Natl. Acad. Sci. USA 2014, 111, 15214-15219. [CrossRef]

34. Xia, S.; Liu, M.; Wang, C.; Xu, W.; Lan, Q.; Feng, S.; Qi, F.F.; Bao, L.; Du, L.; Liu, S.; et al. Inhibition of SARS-CoV-2 (previously 2019-nCoV) infection by a highly potent pan-coronavirus fusion inhibitor targeting its spike protein that harbors a high capacity to mediate membrane fusion. Cell Res. 2020, 30, 343-355. [CrossRef]

35. Ge, X.Y.; Li, J.L.; Yang, X.L.; Chmura, A.A.; Zhu, G.; Epstein, J.H.; Mazet, J.K.; Hu, B.; Zhang, W.; Peng, C.; et al. Isolation and characterization of a bat SARS-like coronavirus that uses the ACE2 receptor. Nature 2013, 503, 535-538. [CrossRef] [PubMed]

36. Menachery, V.D.; Yount, B.L.; Sims, A.C.; Debbink, K.; Agnihothram, S.S.; Gralinski, L.E.; Graham, R.L.; Scobey, T.; Plante, J.A.; Royal, S.R.; et al. SARS-like WIV1-CoV poised for human emergence. Proc. Natl. Acad. Sci. USA 2016, 113, 3048-3053. [CrossRef] [PubMed]

37. Earnest, J.T.; Hantak, M.P.; Li, K.; McCray, P.B., Jr.; Perlman, S.; Gallagher, T. The tetraspanin CD9 facilitates MERS-coronavirus entry by scaffolding host cell receptors and proteases. PLoS Pathog. 2017, 13, e1006546. [CrossRef] [PubMed] 
38. Hoffmann, M.; Kleine-Weber, H.; Schroeder, S.; Krüger, N.; Herrler, T.; Erichsen, S.; Schiergens, T.S.; Herrler, G.; Wu, N.H.; Nitsche, A.; et al. SARS-CoV-2 Cell Entry Depends on ACE2 and TMPRSS2 and Is Blocked by a Clinically Proven Protease Inhibitor. Cell 2020, 181, 271-280.e278. [CrossRef]

39. Liu, S.; Xiao, G.; Chen, Y.; He, Y.; Niu, J.; Escalante, C.R.; Xiong, H.; Farmar, J.; Debnath, A.K.; Tien, P.; et al. Interaction between heptad repeat 1 and 2 regions in spike protein of SARS-associated coronavirus: Implications for virus fusogenic mechanism and identification of fusion inhibitors. Lancet 2004, 363, 938-947. [CrossRef]

40. Lu, L.; Liu, Q.; Zhu, Y.; Chan, K.H.; Qin, L.; Li, Y.; Wang, Q.; Chan, J.F.; Du, L.; Yu, F.; et al. Structure-based discovery of Middle East respiratory syndrome coronavirus fusion inhibitor. Nat. Commun. 2014, 5, 3067. [CrossRef]

41. Xia, S.; Zhu, Y.; Liu, M.; Lan, Q.; Xu, W.; Wu, Y.; Ying, T.; Liu, S.; Shi, Z.; Jiang, S.; et al. Fusion mechanism of 2019-nCoV and fusion inhibitors targeting HR1 domain in spike protein. Cell Mol. Immunol. 2020. [CrossRef]

42. Du, L.; Yang, Y.; Zhou, Y.; Lu, L.; Li, F.; Jiang, S. MERS-CoV spike protein: A key target for antivirals. Expert Opin. Ther. Targets 2017, 21, 131-143. [CrossRef]

43. Huentelman, M.J.; Zubcevic, J.; Prada, J.A.H.; Xiao, X.D.; Dimitrov, D.S.; Raizada, M.K.; Ostrov, D.A. Structure-based discovery of a novel angiotensin converting enzyme 2 inhibitor. Hypertension 2004, 44, 903-906. [CrossRef]

44. Xia, S.; Yan, L.; Xu, W.; Agrawal, A.S.; Algaissi, A.; Tseng, C.K.; Wang, Q.; Du, L.; Tan, W.; Wilson, I.A.; et al. A pan-coronavirus fusion inhibitor targeting the HR1 domain of human coronavirus spike. Sci. Adv. 2019, 5, eaav4580. [CrossRef]

45. Xia, S.; Xu, W.; Wang, Q.; Wang, C.; Hua, C.; Li, W.; Lu, L.; Jiang, S. Peptide-Based Membrane Fusion Inhibitors Targeting HCoV-229E Spike Protein HR1 and HR2 Domains. Int. J. Mol. Sci 2018, $19,487$. [CrossRef] [PubMed]

46. Zhu, Z.; Chakraborti, S.; He, Y.; Roberts, A.; Sheahan, T.; Xiao, X.; Hensley, L.E.; Prabakaran, P.; Rockx, B.; Sidorov, I.A.; et al. Potent cross-reactive neutralization of SARS coronavirus isolates by human monoclonal antibodies. Proc. Natl. Acad. Sci. USA 2007, 104, 12123-12128. [CrossRef] [PubMed]

47. Rockx, B.; Corti, D.; Donaldson, E.; Sheahan, T.; Stadler, K.; Lanzavecchia, A.; Baric, R. Structural basis for potent cross-neutralizing human monoclonal antibody protection against lethal human and zoonotic severe acute respiratory syndrome coronavirus challenge. J. Virol. 2008, 82, 3220-3235. [CrossRef] [PubMed]

48. Ying, T.; Du, L.; Ju, T.W.; Prabakaran, P.; Lau, C.C.; Lu, L.; Liu, Q.; Wang, L.; Feng, Y.; Wang, Y.; et al. Exceptionally potent neutralization of Middle East respiratory syndrome coronavirus by human monoclonal antibodies. J. Virol. 2014, 88, 7796-7805. [CrossRef] [PubMed]

49. Zhou, Y.; Yang, Y.; Huang, J.; Jiang, S.; Du, L. Advances in MERS-CoV Vaccines and Therapeutics Based on the Receptor-Binding Domain. Viruses 2019, 11, 60. [CrossRef] [PubMed]

50. Chen, X.; Li, R.; Pan, Z.; Qian, C.; Yang, Y.; You, R.; Zhao, J.; Liu, P.; Gao, L.; Li, Z.; et al. Human monoclonal antibodies block the binding of SARS-CoV-2 spike protein to angiotensin converting enzyme 2 receptor. Cell Mol. Immunol. 2020. [CrossRef] [PubMed]

51. Wang, C.; Li, W.; Drabek, D.; Okba, N.M.; van Haperen, R.; Osterhaus, A.D.; van Kuppeveld, F.J.; Haagmans, B.L.; Grosveld, F.; Bosch, B.J. A human monoclonal antibody blocking SARS-CoV-2 infection. Nat. Commun. 2020. [CrossRef]

52. Tai, W.; He, L.; Zhang, X.; Pu, J.; Voronin, D.; Jiang, S.; Zhou, Y.; Du, L. Characterization of the receptor-binding domain (RBD) of 2019 novel coronavirus: Implication for development of RBD protein as a viral attachment inhibitor and vaccine. Cell Mol. Immunol. 2020. [CrossRef]

53. Tian, X.; Li, C.; Huang, A.; Xia, S.; Lu, S.; Shi, Z.; Lu, L.; Jiang, S.; Yang, Z.; Wu, Y.; et al. Potent binding of 2019 novel coronavirus spike protein by a SARS coronavirus-specific human monoclonal antibody. Emerg. Microbes Infect. 2020, 9, 382-385. [CrossRef]

54. Lei, C.; Qian, K.; Li, T.; Zhang, S.; Fu, W.; Ding, M.; Hu, S. Neutralization of SARS-CoV-2 spike pseudotyped virus by recombinant ACE2-Ig. Nat. Commun 2020, 11, 2070. [CrossRef]

55. Imai, Y.; Kuba, K.; Rao, S.; Huan, Y.; Guo, F.; Guan, B.; Yang, P.; Sarao, R.; Wada, T.; Leong-Poi, H.; et al. Angiotensin-converting enzyme 2 protects from severe acute lung failure. Nature 2005, 436, 112-116. [CrossRef] [PubMed] 
56. Magrone, T.; Magrone, M.; Jirillo, E. Focus on Receptors for Coronaviruses with Special Reference to Angiotensin-converting Enzyme 2 as a Potential Drug Target-A Perspective. Endocr. Metab. Immune Disord. Drug Targets 2020. [CrossRef] [PubMed]

57. Wrensch, F.; Winkler, M.; Pohlmann, S. IFITM Proteins Inhibit Entry Driven by the MERS-Coronavirus Spike Protein: Evidence for Cholesterol-Independent Mechanisms. Viruses-Basel 2014, 6, 3683-3698. [CrossRef] [PubMed]

58. Zhao, H.; Zhou, J.; Zhang, K.; Chu, H.; Liu, D.; Poon, V.K.; Chan, C.C.; Leung, H.C.; Fai, N.; Lin, Y.; et al. A novel peptide with potent and broad-spectrum antiviral activities against multiple respiratory viruses. Sci. Rep. 2016, 6, 22008. [CrossRef] [PubMed]

59. Shirato, K.; Kawase, M.; Matsuyama, S. Middle East respiratory syndrome coronavirus infection mediated by the transmembrane serine protease TMPRSS2. J. Virol. 2013, 87, 12552-12561. [CrossRef] [PubMed]

60. Hoffmann, M.; Schroeder, S.; Kleine-Weber, H.; Muller, M.A.; Drosten, C.; Pohlmann, S. Nafamostat mesylate blocks activation of SARS-CoV-2: New treatment option for COVID-19. Antimicrob. Agents Chemother. 2020. [CrossRef] [PubMed]

61. Yamamoto, M.; Matsuyama, S.; Li, X.; Takeda, M.; Kawaguchi, Y.; Inoue, J.; Matsuda, Z. Identification of Nafamostat as a Potent Inhibitor of Middle East Respiratory Syndrome Coronavirus S Protein-Mediated Membrane Fusion Using the Split-Protein-Based Cell-Cell Fusion Assay. Antimicrob. Agents Chemother. 2016, 60, 6532-6539. [CrossRef]

62. Engel, J.C.; Doyle, P.S.; Hsieh, I.; McKerrow, J.H. Cysteine protease inhibitors cure an experimental Trypanosoma cruzi infection. J. Exp. Med. 1998, 188, 725-734. [CrossRef]

63. Zhou, Y.; Vedantham, P.; Lu, K.; Agudelo, J.; Carrion, R.; Nunneley, J.W.; Barnard, D.; Pohlmann, S.; McKerrow, J.H.; Renslo, A.R.; et al. Protease inhibitors targeting coronavirus and filovirus entry. Antivir. Res. 2015, 116, 76-84. [CrossRef]

64. Ou, X.Y.; Liu, Y.; Lei, X.B.; Li, P.; Mi, D.; Ren, L.L.; Guo, L.; Guo, R.X.; Chen, T.; Hu, J.X.; et al. Characterization of spike glycoprotein of SARS-CoV-2 on virus entry and its immune cross-reactivity with SARS-CoV. Nat. Commun. 2020, 11, 1620. [CrossRef]

65. Zhou, N.; Pan, T.; Zhang, J.S.; Li, Q.W.; Zhang, X.; Bai, C.; Huang, F.; Peng, T.; Zhang, J.H.; Liu, C.; et al. Glycopeptide Antibiotics Potently Inhibit Cathepsin L in the Late Endosome/Lysosome and Block the Entry of Ebola Virus, Middle East Respiratory Syndrome Coronavirus (MERS-CoV), and Severe Acute Respiratory Syndrome Coronavirus (SARS-CoV). J. Biol. Chem. 2016, 291, 9218-9232. [CrossRef] [PubMed]

66. Zhang, J.; Ma, X.; Yu, F.; Liu, J.; Zou, F.; Pan, T.; Zhang, H. Teicoplanin potently blocks the cell entry of 2019-nCoV. BioRxiv 2020. [CrossRef]

67. Jiang, S.; Lin, K.; Strick, N.; Neurath, A.R. Hiv-1 Inhibition by a Peptide. Nature 1993, 365, 113. [CrossRef] [PubMed]

68. Stoddart, C.A.; Nault, G.; Galkina, S.A.; Thibaudeau, K.; Bakis, P.; Bousquet-Gagnon, N.; Robitaille, M.; Bellomo, M.; Paradis, V.; Liscourt, P.; et al. Albumin-conjugated C34 Peptide HIV-1 Fusion Inhibitor: Equipotent to C34 and T-20 in Vitro With Sustained Activity in SCID-hu Thy/Liv Mice. J. Biol. Chem. 2008, 283, 34045-34052. [CrossRef]

69. Chen, X.; Lu, L.; Qi, Z.; Lu, H.; Wang, J.; Yu, X.; Chen, Y.; Jiang, S. Novel Recombinant Engineered gp41 N-terminal Heptad Repeat Trimers and Their Potential as Anti-HIV-1 Therapeutics or Microbicides. J. Biol. Chem. 2010, 285, 25506-25515. [CrossRef]

70. Wang, L.; Shi, W.; Chappell, J.D.; Joyce, M.G.; Zhang, Y.; Kanekiyo, M.; Becker, M.M.; van Doremalen, N.; Fischer, R.; Wang, N.; et al. Importance of Neutralizing Monoclonal Antibodies Targeting Multiple Antigenic Sites on the Middle East Respiratory Syndrome Coronavirus Spike Glycoprotein To Avoid Neutralization Escape. J. Virol. 2018, 92, e02002-e02017. [CrossRef]

71. Ota, S.; Hara, Y.; Kanoh, S.; Shinoda, M.; Kawano, S.; Fujikura, Y.; Kawana, A.; Shinkai, M. Acute eosinophilic pneumonia caused by camostat mesilate: The first case report. Respir. Med. Case Rep. 2016, 19, $21-23$. [CrossRef]

72. Keck, T.; Balcom, J.H.; Antoniu, B.A.; Lewandrowski, K.; Warshaw, A.L.; Fernandez-del Castillo, C.F. Regional effects of nafamostat, a novel potent protease and complement inhibitor, on severe necrotizing pancreatitis. Surgery 2001, 130, 175-181. [CrossRef]

73. Fosgerau, K.; Hoffmann, T. Peptide therapeutics: Current status and future directions. Drug Discov. Today 2015, 20, 122-128. [CrossRef] 
74. Chen, R.Y.; Kilby, J.M.; Saag, M.S. Enfuvirtide. Expert Opin. Investig. Drugs 2002, 11, 1837-1843. [CrossRef]

75. Su, S.; Rasquinha, G.; Du, L.; Wang, Q.; Xu, W.; Li, W.; Lu, L.; Jiang, S. A Peptide-Based HIV-1 Fusion Inhibitor with Two Tail-Anchors and Palmitic Acid Exhibits Substantially Improved In Vitro and Ex Vivo Anti-HIV-1 Activity and Prolonged In Vivo Half-Life. Molecules 2019, 24, 1134. [CrossRef] [PubMed] 